


\title{
2.-ledstryk og andre sprogformer i Kortvending
}

\author{
Af Lars Brink
}

A new and brilliant diplomatic edition of »Kortt wendingh« appeared in 2013, following MS AM $808,4^{\circ}$. The editor was $\dagger$ Leif Stedstrup. The edition contains a so-called »school comedy« written by Hans Christensen Sthen in c. 1570. Sthen was born in 1544 and grew up in Roskilde. His hymns, some of which are still sung, are well known, but his language is not particularly well researched. I have tried to extract all of the interesting pronunciations and a few of the grammatical features that occur in »Kortt wendingh «. It has not proven to be an easy task because Danish orthography in the sixteenth century was somewhat complex and can be difficult for us to evaluate today. But as all alphabetical writing encapsulates the pronunciation of its time, I think that such a linguistic investigation can be undertaken and provide information about late sixteenth-century Danish pronunciation on Sjælland.

(Incidentally, »Kortt wendingh « is both the name of the main character (cf. the English name Curt) and a phrase in Danish meaning a 'sharp vicissitude' (concerning one's fate), which is, indeed, the topic of the play).

\section{Formål}

Formålet med min undersøgelse er at uddrage nye, upåagtede udtaler af H.C. Sthens »Kortvending «.

H.C. Sthens lange (og i dag kedelige) komedie kom i en glimrende udgave ved Leif Stedstrup, DSL, i 2013. Her har vi en kilde, der kan dateres (ca. 1570), skrevet af en bekendt åndsperson, Hans Christensen Sthen, hvis opvækststed og fødselsår vi kender (Roskilde 1544), hvis mange andre værker vi kan sammenligne den med, og som desuden er en sikker versifikator. For en lydhistoriker er kilden stærkt fristende. - Formålet udgøres af 3 delformål:

1) Tryk. Jeg har i de senere år udbygget, korrigeret og præciseret den sproghistoriske tryk-opfattelse i Dansk Rigsmål §85, nemlig i Brink 2018a, b, 2019. Heri hævdes det, at der i 1300-tallet skete en trykomkastning fra 1.-led til 2.-led i tunge ord (en lydlov), der imidlertid i 1600-tallet delvis tilbageføres (ikke lydlov). Mine undersøgelser omfatter hele sproghistorien fra olddansk til i dag og bygger på et langt større materiale end Sthens. Og til dét kan lægges Eli FischerJørgensen 2001's store materiale, som jeg har gennemgået (hun behandler ikke Kortvending). Men naturligvis er en bekræftelse gældende for 1500-tallets sjællandsk velkommen. 
2) Punkt 1 har fået mig til at gennemtænke, hvordan man - fra bunden og detaljeret - uddrager tryk-oplysninger af vers. Det er ikke gjort før, idet alle hidtil er gået impressionistisk til værks.

3) Der er andet end tryk hos Sthen. Jeg fremdrager alle upåagtede, ofte overraskende, udtaler hos ham.

\section{Metrum og materiale (delformål 2, der naturligt må komme før 1)}

Sthen benytter i Kortvending 4 metre:

1) (det dominerende): 0,1 el. 2 optaktstavelser, dvs. tryksvage stavelser før 1. trykstærke i linjen (i praksis langt oftest 1 optaktstavelse; sjældnest 2: ca. 10\% af linjerne). Så 4 toppe (også kaldet hævninger) med mellemliggende 1 el. 2 dale (også kaldet sænkninger). Linjens sidste el. 2 sidste stavelser er rimstavelser, enten mandlige eller kvindelige, altid i par (parrim), men derudover ej fast rækkefølge. Kvindelige rim har aldrig bitryk, dvs. er aldrig af typen bjergtop dvaergkop. - I dette metrum er der 3.333 dansksprogede verslinjer a 4 versefødder $=13.332$ versefødder.

2) Epilogen: Som ovenfor, men i de lige linjer kun 3 toppe (altså 4+3, $4+3 . .$.$) , og fletrim. -$ I alt 148 linjer, hvoraf de 74 a 4 fødder, de andre 74 a 3 fødder $=296+222=518$ versefødder.

3) Indledningsstrofe til visetillæg: 4 linjer. Optakt som ovenfor og $6+6+6+4$ toppe. Mandlig udgang. 1. linjepar rimer, 2. ikke. - I alt 22 versefødder.

4) Visetillæg: 11 visestrofer a 7 linjer (= 77 linjer), der skal synges. Fast 1 optaktstavelse og 3 toppe i hver linje, dog har omkvædet i sidste vise 2 linjer med 4 toppe, i alt 84 -toppede linjer. I alt $(69 \cdot 3)+(8$. 4) $=239$ versefødder. Fletrim, parrim og klamrerim.

Alt i alt 3.562 verslinjer med 14.111 versefødder.

\section{Fejlprocent}

Fejlprocenten belyser Sthens pålidelighed. For at kunne uddrage trykoplysninger må vi vide, hvor pålidelig han er. Først skal vi se på nogle eksempler på fejl hos Sthen, og tryk-uddragning (af mig). I 1. akt, linje $568(=1.568)$ 


\section{Oc 'idelliig 'Løbitt epther 'herre 'hoff (...fornemme forsamlinger)} er der uimodsigeligt 3 dale i træk ('løbet efter). Og vi får i øvrigt intet at vide om trykket i herrehov, fordi bitryk, hvor det end lå ('herre, hov eller herre'hov), i al metrik kan løftes til hovedtryk. (jf. Brink 2019). - I sidste linje, 3.689, af rimparret

Theris 'pening oc 'gotz huadtt 'the for'maathe (...besad)

Theris gulld oc ßøllff huad the otthe (...alt, hvad de ejede) er der kun 3 toppe. Theris kunne evt. have top, men da foregående linjes Theris ikke kan have det, og de jo skal være parallelle, bortfalder muligheden. Derimod kunne der tænkes en spondæ (...'ßøllff 'huad..., med hvad i nuancen 'hvad som helst'), også en fejl, thi Sthen skyr spondæer, se ndf. - I 3.132

$O$ 'werden 'huillken 'stor for'reder est 'thu ( 'nu) er der 5 toppe - eller følgende 3 ret »syge« dale i træk: 'hvilken stor for'rceder. Sthen kan dog frifindes, hvis han i virkeligheden digtede .... hvad 'stor..., der blot blev forfremmet til hvilken ved nedskrivningen, hvad jeg egentlig tror (hvilken har altid været talesprogsfjernt).

At Sthen ikke bevidst tilsigter 5 toppe, fremgår dels af, at linjen helt er omgivet af 4-toppede, men også af, at hverken middelalder eller 15- og 1600-tal kender metre med 5-toppede linjer. Først 1773 dukker de berømte 5-fodsjamber op i Danmark (Arnholtz 1961: 25, Fafner 1995).

I 1.922

Ett 'skøntt syl'bellthe, oc 'anden god 'Thing (...sølvbælte..., mandlig rimudgang)

er der ingen fejl, og udtalen sølv'baelte fremstår ren og pur. Hvis den skulle betvivles, måtte man operere med en spondæ (et 'skønt 'sølv...), eller kun 3 toppe i linjen, dvs. skønt i dal; eller nok 4 toppe, men da grov omvending: 'et skønt 'sølvbcelt(e) og 'anden god 'ting, dvs. 'et skønt (om omvending se Brink 2019) i stedet for det naturlige et 'skønt, altsammen er utilstedeligt, og, som vi snart skal se, så uhyre sjældent hos Sthen, at vi er berettigede til at se bort fra det. - Hvis, omvendt, fx udtalen 'hovmod betvivles i 1.62

Saa 'lade the 'thennom aff'hoffmodt' 'blynde $\quad$ (blinde $\sim$ quynde $=k$ vinde) så ville man med et hov'mod ikke kunne undgå en styg spondæ til sidst, eller en ligeså fæl omvending: 'af ${ }_{0}$ ov ${ }_{\mathrm{o}}$ mod, hvilket sidste endda ville forudsætte, at dennem læstes i 2 stavelser, hvor Sthen langt oftest har det som 1 , se ndf. - I 1.708

Rymsnider gierningh kandtt ieg mett $\quad$ (rem-skærer-gerning...) kan man derimod intet sikkert uddrage om remsnideren, for både 'remsnider og rem'snider passer fint med metret. (Dog har han som nævnt langt 
oftere 1 optaktstavelse end 0). - Pga. de 3 optaktsmuligheder og hans traditionelle vekslen mellem bi- og trisyllabisk gangart ( 1 el. 2 dale $\mathrm{ml}$. toppene) er der hos Sthen ganske mange tvetydige tilfælde.

Herefter kan fejlene tælles:

\begin{tabular}{|c|c|}
\hline $\begin{array}{l}1.569 \\
\text { toppe } \\
\text { (el. } 5 \\
\text { entze }\end{array}$ & $\begin{array}{lrrrr}\text { el. } 5 \text { toppe) } & 1.908 & 2.568 & 3.182 \text { (el. } 5 \text { toppe) } & 3.275 \text { (el. } 5 \\
\text { oprindelig vel uden oc hvorved alt passer) } & 3.312 & 3.525 \\
\text { oppe) } & 3.1053 \text { (el. } 5 \text { toppe) } & 3.1123 \text { (el. } 5 \text { toppe el. 'Pestel- } \\
\text { den sidste -ə) } & 3.1343 \text { (el. } 5 \text { toppe) } & 3.1493 & 3.1672 & 3.1675 .\end{array}$ \\
\hline $\begin{array}{l}1.621 \\
\beta \text { Buer }\end{array}$ & $\begin{array}{l}\text { der bevidst) } 1.7253 .1292 \text { (lyder bevidst) } 3.1500 \text { (el. } \\
\text { r' skal læses 'su'ər, hvad jeg hælder til). }\end{array}$ \\
\hline toppe pro 4 & 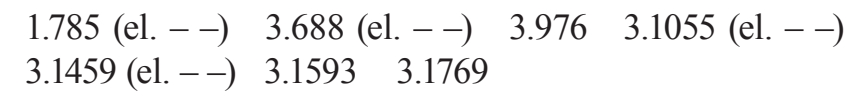 \\
\hline oppe pro 4 & $\begin{array}{l}1.121 .343 \quad 1.751 \text { (el. ej pro icke') } 2.512 \text { (el. ej pro icke) } \\
3.132 \text { (el. hvad pro huilken) 2.763 (el. ej) } 3.477 \quad 2.192 . \\
3.7353 .10843 .1498 \text { (el. }\end{array}$ \\
\hline
\end{tabular}

Fejlenes antal bliver da: max. 36 - og min. 28 - fodfejl i 14.111 versefødder. Altså yderst beskedent.

\section{Fejls relevans}

Disse få fejl er imidlertid ikke særlig relevante, selvom de, sådan alment, giver et godt indtryk af Sthens gehør. For de vildleder slet ikke forskeren mht. udtalen. At Sthen stundom nøjes med 3 fødder i stedet for 4, eller sløser sig til 3 dale i træk, eller forgriber sig på spondæer, gør ikke hans udtale uklar. For det er her i alle tilfælde dagligsproget, der sejrer på metrets bekostning. Skulle han virkelig ønske sådanne steder udtalt metrisk korrekt, ville udtalen gå rent amok. Hvis $\mathrm{fx}$

Theris gulld oc Bøllff huad the otthe (...alt, hvad de ejede) skulle udtales metrisk korrekt, ville vi få

\footnotetext{
1 Jeg tror på $e j$ og dermed fejlfri digtning. Brøndum-Nielsen 1951 har glimrende vist, at $e j \mathrm{i}$ 1500 -tallet fortrænges af $i k k e$ adv. i skriftsproget (bortset fra de kendte 2 fraser). Men talen var sikkert trægere, idet Kristensen 1894 har et belæg på jysk dialekt ej hos mand f. ca. 1690.
} 
Deres 'guld og 'sølv hvad 'de åt'te ! (2 optaktstavelser + 4 toppe med max. 2 dale imellem)

Og skulle spondæen i 1.725 :

Skulle giørre diigh thiil ind arm mand

være tænkt undgået af Sthen, måtte linjen være tænkt udtalt:

'Skulle 'gøre dig 'til en arm 'mand!

De fejl, fonetikeren frygter, er dem, hvor metret intenderes at sejre over dagligudtalen, dvs. »omvendingerne«. Hvis tante Agathe i konfirmationssangen skriver:

Til Skcelskør kom en gammel mand,

og vi ikke i forvejen kendte udtalen af Skcelskør, så vildledes vi til at tro på et 'Skcelskør. Det er slige fejl, vi må frygte som gift. Men hvis man begår fejl i ny og næ af ovenanførte slags, vil man så ikke også begå omvendingsfejl? Ingenlunde. Thi hine er meget mere uskyldige $\mathrm{i}$ og med, at de ikke forvrider dagligudtalen. Hvordan kan vi teste »omvendingerne $\ll$ ?

Det gør vi ved at slå ned på en række ord, hvis tryk er stensikre - og så se, om Sthen kan finde på at »omvende« dem. Ingen har historisk næret tvivl om trykket i ord som i'gen, for'vandling, 'fattig(e), 'Jesus, i'mod, for'gcette, 'rigdom, be'tcenke, 'blodig(e) osv. (Vi går uden om mulig »omvending « i ə-ord: 'skole, 'kegler. Ingen professionel finder på at skandere sig'er, sam'let osv. Vi undgår også typen underlig, viselig, da de oftest, helt traditionelt, står med 2 toppe, hvad der intet siger). Og vi vælger de første 25 slige sikre ord, som vi kontrollerer, i den digitale udgave, i hele værket. Dog, for ej at overanstrenge os, kun de første højst 10 belæg. Ordene er følgende:

arlig, til stede, omkring, bestilling, beskikke, forstand, besinde, daglig, foragte, hellig, forvandle, saivel, moegtig, aldrig, snarlig, igen, rigdom, forvandling, fattig, Jesus, imod, lardom, forgatte, person, regere. Inkl. bøjningsformer heraf.

I alt 138 belæg. Hvis Sthen har »omvendinger« heriblandt, vil det altså sige, at han lig amatørerne kan finde på at angive: cer'lige, 'omkring, 'beskikket, 'personer osv. Helt konkret ville det betyde, at vi de steder, hvor vi uddrager interessante tryk som op'høje i fx 3.23:

Theße 'andre ieg 'strax op'høge 'wiill dér kunne det tænkes, at han privat siger 'ophøje og blot vil undgå en spondæ - og altså tyr til »omvending« (op'høje i stedet for 'ophøje).

Min kontrol af de 138 former viser, at der faktisk er 3 »omvendinger«, alle i ordet rig'dom, og alle i rimstilling: 
Thynn 'Broder skall 'wendis 'Lycken 'om

Oc 'hand skall 'fange 'alltt thynn Rig'dom.

(1.847. De to andre steder, 3.1021 og 3.1315, er tilsvarende).

Bortforklaring er umulig. Han har ikke her kunnet klare rytme og rim fejlfrit. - Kunne han fakultativt have haft rig'dom i egen tale? Det tror jeg ikke; mit store tryk-korpus viser ikke et eneste eksempel på 2.-stavelsestryk i den tostavede afledning: visdom, laerdom, sundhed, troskab, varsom..., og i øvrigt har han 33 belæg på 'rigdom. - Vi må trøste os med, at når metret viser et interessant tryk hos ham, er der $(138 / 3=) 46$ gange større chance for, at det dækker hans udtale, end at det er er en lygtemand.

\section{Trykomkastningen i 1300-tallet}

Interessante udtaler hos Sthen omfatter som sagt de mange 2.-ledstryk. De opstod ifølge Brink 2018a-b i 1300-tallet. Og reglen var følgende:

»Tunge ord «, dvs. ord, der ubøjet har mindst 3 stavelser med mindst 2 hoved-/bitryks-bærende fuldvokaler får - på nedennævnte undtagelse nær-TRYK-OMKASTNING fra 1. til 2. fuldvokal-stavelse.

Sammensætnings-grundtypen på 2 stavelser, stenhus, selvdød, sker der altså intet med (på Sjælland; men Læsø, Fyn, Sønderjylland og Skåne får også talrige 2.-ledstryk dér; Kortetc. 136); ofte heller ikke i bøjet form: stenhuse osv. (Sthen har desværre ingen sikre tryk-belæg her). Og tilsvarende sker der ingen omkastning i de 2-stavede afledninger som mandbar, sandhed (der i vid udstrækning havde svagtryk i stedet for nuværende bitryk, Da.Rm. p. 507f.), ligesom disses bøjningsformer, frugtbare, venskaber osv., altid følger grundformen.

Omkastningen gælder altså først og fremmest typen vidunder, tinglyse med hoved-+bi-+svagtryk, idet denne er i størst trykmæssig ubalance, den bliver mere bekvem at sige med svag-+hoved-+svagtryk, hvorimod der ikke er stor gevinst at hente i typerne 'sommer fugl og 'hjerte, kammer, som kun i svag grad rives med (ligesom bøjningsformerne ofte følger simpleks: 'sommer, fuglen, 'hjerte, kamrene. Sthen har konsekvent 1.-ledstryk i alle disse uanset bøjning). Uantastet er også den lignende type 'sjcellandsfar(er) med sammensat 1.-led.

Disse tunge ord er jo næsten alle sammensætninger eller afledninger, men strengt taget ignorerer udviklingen dette, idet den lige fuldt rammer 
de ord i sproget af nævnte struktur, der ikke er sammensatte, eller hvor "2.-leddet" slet ikke er noget led: ar'bejde,em'bede, even'tyrlig, al'vorlig. Der er faktisk tale om en regulær lydlov.

Omkastningen er ikke, hvad man kunne tro, begrænset til naboskab af hoved- og bitryk. For wederhettig, der oprindelig må have haft nordisk 1.-ledstryk, ændres > veder'hoeftig. Også even'tyrlig forklares sådan; ordet er belagt i Kalkar i 1575, men ej i GDO, dannet i dansk af 'eventyr. Tilsvarende neder'drcegtig lånt før $1737<$ hty. 'niederträchtig, det må have tilpasset sig omkast-stadiet.

En mærkværdighed er det, at 2-stavede verber, fx ind'gå, ned'kom, ganske følger de 3-stavede verber (men altså ikke de andre 2-stavede ordklasser: 'stenhus, 'mandbar). Min forklaring er, at disse verber (2- som 3-stavede) går tilbage til »ægte sammensatte verber« med det fra tysk kendte svagtryk på 1. led. Men her må jeg nøjes med at henvise til Brink 2018b.

Desuden gælder det, at substantiver afledt af verber med 2.-ledstryk, følger verbets tryk: at'trå, årceth 'overfald' (og, naturligvis, »tunge« som vel'signelse, an'søgning).

Endelig $u$-. Det var et af de få præfikser, der overlevede i urnordisk. Det var som sådant tryksvagt (som alle præfikser i urgerm.). Men kunne af naturlige grunde let få emfatisk tryk. Der har altid været - og råder stadig - kaos her: u'artig, u'rolig, ufor'lignelig vs. 'uklog, 'ustabil, 'uforscetlig, men 2.-ledstryk var endnu mere almindeligt tidligere.

\section{Gamle udtaler og konventioner at beagte hos Sthen}

For at kunne skandere Kortvending (dvs. bestemme toppe og dale som tænkt af digteren) så korrekt som muligt - og derved uddrage sikre udtaleoplysninger, må man selvfølgelig erkende så meget som muligt af hans udtale, hvor den afviger fra nutidens. Her skal følgende fremhæves.

1. Hiat-apokope, dvs. apokope af tryksvag udlydende vokal foran anden - trykstærk el. tryksvag - vokal i næste ord, er næsten gennemført. Denne apokope var velkendt i middelalder og Sthens samtid og kendes fra mange europæiske poesier; er fx levende i den spanske ('Bésame, 'bésame 'mucho / 'Como si 'fuera esta 'noche la 'última 'vez) og den nyislandske ('Drottin 'vakir, 'Drottinn 'vakir / 'daga' og 'ncetur 'yfir 'pér). Jeg vil tro, at den afspejlede talen, dels fordi den er meget naturlig, dels fordi den er næsten obligatorisk hos Sthen: Hvis den ikke var almindelig i tale, ville 
det være svært at gennemføre den ved nedskrivning, når verset nu éngang først udtænkes skriftløst. I talrige tilfælde kan man naturligvis ikke se Sthens evt. hiat-apokope, idet der er valgfrihed mellem 1 og 2 dale i træk, men oftest kan man: 2.576:

Oc Liid ther Baade forßmedelße oc spott (Liid = 'lidt' part. Uden apokopen: 3 tryksvage i træk el. 5 toppe inkl. -'se, begge dele forbudt)

Menn 'Inthett' 'acte om then 'arme 'hiordt. (1.465. Uden apokopen: 5 toppe el. 3 tryksvage i træk el. omvending: 'den arme $\mathrm{i}$ stedet for ${ }_{0}$ den 'arme)

En sjælden gang markerer Sthen apokopen:

'Blandtt Landtz 'kneckett_oc 'fare i 'krij (3.1401. Landsknoegt kan umuligt have haft nul-plur.)

Nu Lather os dantz_oc quede mett werßens frydtt oc Lyst

(tillæg lin. 6. Der skal være 6 toppe i linjen)

Aage Hansen 1962: 243 mener også, at hiat-apokopen tilhørte talen, men kun fakultativt, hvorimod den skulle være mere konsekvent i poesi, helt til begyndelsen af 1700-tallet.

2. Apokope efter tryksvag stavelse. Udlydende vokal efter dal-stavelse i samme ord droppes ofte. Men i stedet for at give skuespilleren en hjælpende hånd til skandering, noteres vokalen altid fuldt ud i respekt for skriften, fx 1.15, 1.187, 1.256, 1.287:

Huilcke 'wunderligh 'tingh y'verden monne 'skee

'Stundum hagdê'hand al 'uorlige 'facthe (Må skanderes sådan hvis det skal være uden fejl)

The 'riighe schulle 'myste 'godz og 'penning (Uden apokopen er der 5 toppe el. 3 dale i træk)

Meg 'løster att 'høre thenne 'greffue 'snack

Der er her tale om den lydlov, der beskrives i GG §219.3, og som har ført til velkendte former som Embed, dansed, Husbond, Roskild, Vindu, Himmerig, Albu, Sverrig, Tørkle, Herberg, Morder, Kong, Herr. (Den må være ældre end »trykomkastningen«, eftersom apokopen friholder sådanne ord for trykomkastning).

Undertiden negligerer Sthen dog skrifttraditionen og noterer apokopen, 1.648:

Mynn 'peninge 'staar alltt 'mig $i$ 'huge 
Og et enkelt sted har jeg bemærket en omvendt form: falsk $e$, 3.1613: Att 'handtt mig 'heller wille 'fattiige 'haffue (wille har herhenh. apokope, mens fattiige har omvendt $-e)$

At Sthen vitterlig har disse to nævnte apokope-typer, belyses af Hieronymus J. Ranch, der er langt mere øm om at lade sine apokoper være tydelige. Han har i »Karrig Nidding « (ca. 1600) talrige markerede apokoper. Eksempler fra de 2 første sider hidsættes her for at vise, hvor almindeligt det var at digte vers uden visse i skriften obligatoriske stavelser:

Den anden hafd hiem i Grcecken Land/-Den Jutta var hans Ecte-Qvind'/ (Ranchs apostrof) - Den Pig' Philissa red' deris Seng/-Men effter Spien matt hun snage/'hun måtte rode i opkastet' - Hand tient Nidding til Haand og Mund/ - At giffve nock baad 'Øll oc Brød/ - Dend Staader Jeppe kom lackend $i$ Gaarde/ - Jeg slucker ud baade Arn oc Ild/ - Maa det ey ver en underlig Ting/. Ældste hs. er posthumt, fra 1664; det forekommer mig udelukket, at en afskriver bevidst dropper stavelser i forlægget, der er obligatoriske i almindelig skrift. Men skúlle jeg tage fejl her, viser afskriften alligevel, at en mand født ca. 1600 ville oplæse digte med en mængde apokoper.

\section{Kortformer}

For at skandere Sthen korrekt (og dermed kunne uddrage udtaleoplysninger) må man kende de mange andre tilfælde, hvor et ord skal udtales med en stavelse mindre, end skriften viser. Sthen skriver dem i respekt for traditionel skrift med en stum stavelse. Til malefice for læser og skuespiller. Meget ofte står den bortfaldne stavelse i abbreviatur, så at abbreviaturtegnet kommer til at fungere som et »denne stavelse er stum«. Kortformerne er sjældent overraskende; de er standard i dialekterne og i kbhsk. flere hundrede år tilbage. Men at få dem konkret belagt i 1500-tallets sjællandsk har alligevel også interesse i sig selv.

For og ther fore. Ordet for skrives altovervejende $<$ for $>$, men dog ca. 30 g. < fore >. Det sidste kan ofte udtales frit i 1. el. 2 stavelser, men flere steder dog kun i 1 stavelse, fx p. 147. Jeg går ud fra, at den oldskandinaviske 2-stavelsesform forlængst var forsvundet fra talen (bortset fra fore-). - Ordet derfor skrives 7 g. $<$ therfor $>$, uden tvivl om stavelsesantallet. Udtalen er 'derfor eller der'for. 14 g. skrives det $<$ ther for(r)e $>$ (sjældent i ét ord). Alle tilfælde er tvetydige efter metret -2 elller 3 stavelser - men lyder bedst med kun 2 stavelser. Jeg går ud fra, at dette sidste, ligesom ved sim- 
pleks for, var obligatorisk i daglig tale, hvad også den hyppige abbreviatur antyder.

dennom o.l. 'dem' er normalt énstavet. Fuldformen har næppe nogensinde eksisteret, men er oprindelig hyperkorrekt efter hanom, der dog hos Sthen også oftest er énstavet som ham i dag, fx Tha hagde hanem Liidtt saa well som meg, 1.824 .

mennisckelig 1.235 må skanderes »menskelig«.

Broder, fx $1.422^{2}$, står énstavet (1. gang har det begge mul.). Fuldform i 2.53 .

Al'ligeuel, fx 1.427, står med stum 3. stavelse. I 1.439 synes udtalen at være 2-stavet: »a'liw'l«.

Predicke(n) vb., sb., fx 1.437, står 2-stavet.

wthi 'udi' læses næsten altid (der er dog tvetydige steder) blot $i$. En almindelig skriftkonvention.

anderledis i 1.467 og 3.723 har kun 3 metriske stavelser. Det må dreje sig om ['an, le'ns], som er velbelagt i ældre lav-kbhsk. og sjællandsk. Der synes ikke at være andre passende udtaler.

meden 'mens', fx 1.511, læses vist altid énstavet.

haffuer vb. 'har' læses næsten overalt énstavet, som i dag. Til gengæld synes inf. have altid at have 2 stavelser. Ordets uregelmæssige $v$-tab er givetvis begyndt $i$ den almindeligere og tungere præsens, sml. nuværende $<$ blir $>$ hos flere forfattere vs. det sjældne $<$ blie $>$. Tilsvarende læses giffuer normalt gir, mens giffue altid står 2-stavet.

peninge fx 1.658 må læses penge, som i dag.

Berer vb. 'bærer' 1.751 må læses bcer, den almindelige og oprindelige form (Da.Rm. §76).

eder pron., fx 1.914, må læses énstavet, dvs. som jer.

fanger vb. 1.928, 1.948, 2.11 må læses får, og ganger 3.976 som går.

theris 'deres', fx 2.25, læses som det ældre og oprindeligere der (oldn. peira), men opfattes åbenbart som det mest korrekte.

Lader vb., fx 2.153, læses énstavet, som i dag.

syndere sg. 'synder' 2.378 må læses tostavet, enten som synder eller det typisk sjællandske syndre. Tilsvarende komparativ Rigerre $=$ rigre 3.1606 .

Lige som, fx 2.566, må læses lisom, som i dag.

Ideligger 'ideligere, oftere' 2.719 og idelliig 3.1457 må skanderes 'idliger hhv. 'idlig ligesom det synonyme adj. idig (nu dial.), hvad der er umuligt i dag. Ordet var vel mere almindeligt dengang, jf. temlig, almindlig, vœemlig m.fl. i dag. Tilsvarende læses dygdelliig 3.784, Blidelig 3.1006 og euindelliig 3.1682 som hhv. dydlig, blidlig og evindlig. 
wden 'uden' 3.60 må læses énstavet, vel $=[u \cdot n]$, jf. ikke uden $>i k k u n$. Sjællandsk og fynsk har ofte 1 stavelse, uden $ð$.

hymmelen 3.288 må læses himlen, som i dag.

peder 'laalle 3.410, 3.413, 3.435 må læses per..., den normale udtale af Peder.

wppaa skal langt oftest siges fuldt ud med stærktryk på 2. stavelse (når stavelsestallet kan afgøres). Kun ét sted, 3.438, skal det læses ['på'].

Thiennisten 3.490 må læses tjensten i god harmoni med Tiennsthe piigenn 3.1570.

Piger 3.682 må læses pir, som i dag.

eniste 'eneste' 3.738, 3.1579 må læses enste, hvad vi ikke siger i dag, men har en refleks af i enesteskilling '1-skillings-mønt' (se ODS), der altid udtaltes enste-. Vi venter ikke nutidig restitution i dette almindelige ord (eneste), men det må huskes, at der er to komparationer, en lang (skønneste) og en kort (lcengste, tidligste). Den lange har senere sejret. Også Alleniste 3.1803 må læses alenste.

mener 3.1074 må læses men, en velkendt ældre og dialektal præsens.

Raader vb. 3.1156 læses rår, som delvis i dag (Mennesket spår,...).

forre 'tidligere' læses ofte $f \varnothing r$, fx 3.1725. Førre er opr. et adjektiv, før et adverbium, begge i komparativ.

\section{Resultater}

2.-ledstryk ifølge trykomkast-reglen, men forladt i mod. rm. (Jeg beskriver ikke her den langsomme overgang til 1.-ledstryk i kbhsk. og rm. Se Da.Rm. $§ 85$ og Brink 2018b):

mys'tencke, op'høygis 2 g., op'høge, op'høgitt, till'gaa, till'føyge 4 g., op'rette, om'bcere 'undvære' 3 g., aff 'hullden 'afholdt', om'uende 2 g., om'uendtt 2 g., wd'sentt, aff 'gaa, op'berre 'oppebære', hel'brede sb., thiill 'falle, Spanß'meßing 'spanskmessing', wnd'gaa, kortt 'Vendning 8 g., Em'beder 3 g., em'bede, Sko'gierning, paa 'førtt, fram 'førde inf., op'ede, paa'gaar, syl'bellthe 'sølvbælte', gulld 'Rynghe 2 g., Ind'ßett 'indsat', op'schriffue, gen'løst, tiill'ßende, Stald'mestheren, wer'actiig 'fortjent til ngt.', ar'beyde sb., stalld'drenghe, handtt'klede, hoff'gierning, till'stunde, tiill'ßentt, fram'berre, Bortt'skiffte, tiill'kum præt., tiill'stande, tiill'staa, ad'traa sb., op'uectt vb., tiill'hørde, op'tagiitt, mord'Brender, paa'kasther, om'kast 'omkastet' 2 g., op'retthe, op'hollde, op'hentte, tiill'ßlar 'tilslår', 
tiill'slaa, op'regne, wnd'slar, kiøb'slaar, wi'under (ordet vidunder = 'spot'), om'skiffthe, op'lede, well'kledde 'velklædte', Vd'huggen, kiøb'slaa, fioll'farie 'violfarve' sb., op'stande, mett'gaffue 'medgift', yd'myge vb., paa'Røre vb., Bortt 'ßette. I alt 91 belæg.

2.-ledstryk ifølge omkast-reglen, bevaret i mod. rigsmål: at'skillige, al'delis, lyck'saligh 3 g., lyck'ßalige, fruct'ßommelig, Spag'ferdige, hoff'modige, hoff'modig, fred'ßommelige, om'uendeligh 7 g., hug'sualle sb. 3 g. 'trøst', hug'sualle vb., hug'ßualliitt, løß'actiighett 2 g., e'lendiighedtt, vell'ßinellße, toll'modiighet, all'mindelliig, hyg'tiidelliig, w'Biigellig, Barm'hiertighett, Barm'hiertige, fulld'kommelliig, mis'kundelig, om'giengells, Ee'uindelliig 4 g., om'sckiffthellig 2 g., Rett'ferdighe adj. pl., Rett'ferdiig, all'mectigste. I alt 45 belæg.

\section{Undtagelser}

1.699, 1.724 og 3.1007 har det regelrette em'beder; en del steder med embede(r) er trykmæssigt tvetydige, men ét sted, 2.534, har entydigt det regelstridige 'embeder. Ordet skrives desuden 11 g. 2-stavet: embitt o.l., altid, naturligvis, 'embed. 2-stavelsesformen er kendt lige fra ca. $1300 \mathrm{og}$ til i dag: på embeds vegne, $i$ embeds medfør (ODS). Det ene 'embeder er derfor sikkert kontamineret med 'embed. En anden nærliggende årsag er, at ordet kunne have svagtryk i stedet for bitryk: 'embəðə (jf. nuværende 'embəðs-), hvorved det unddrager sig trykreglens skopus for tunge ord.

Arbejde minder meget herom. Det skrives entydigt ar'beyde sb. 2.501 og har en række tvetydige steder, men står entydigt som 'arbeyde vb. 2.634. Også dét kan skrives i 2 stavelser, arbeyd o.l. sb. med en fra de ældste tider og op gennem hele 1800-tallet kendt form (ODS, jf. arbejds-). Og også her konkurrerer det med en form uden bitryk, kendt fra dialekternes 'arbə(ð), ØMO. Dermed turde 'arbeyde vb. være bortforklaret.

\section{Foreløbig konklusion}

Sthen har altså i alt 91 belæg på 2.-ledstryk, der i dag har 1.-ledstryk. Hvis disse i virkeligheden havde 1.-ledstryk i Sthens spontane sprog, men skyldtes rytme-nød (»omvending «), måtte man vente, at de oftere stod med deres sande tryk. En stærk bekræftelse på tryk-omkastet. 
Men Sthens 45 2.-ledstryk i ord med nutidigt bevaret 2.-ledstryk gør det endnu klarere, at han ikke tyr til licens: Betragt mængden af nutidsord med 2.-ledstryk, der tilfældigvis forefindes i »Kortvending«. Ifølge tryk-omkastet skulle de meget gerne være ramt i 1300-tallet og dermed have 2.-ledstryk hos Sthen, for der kendes ingen andre lydudviklinger, der kunne give dem 2.-ledstryk. Det har de også - 45 gange. På forhånd er der 2 muligheder: 1.- eller 2.-ledstryk hos Sthen. Sandsynligheden for, at de 45 gange i træk tilfoeldigt har 2.-ledstryk, er $1 / 2^{45}=$ ca. 1 ud af 35 billioner.

\section{1.-ledstryk ifølge reglen}

Loven om tryk-omkast $\mathrm{i}$ tunge ord bekræftes, når vi ser de tunge ord optræde med 2.-ledstryk hos Sthen. Men hvis lettere ord også får trykomkast, er den alligevel ukorrekt opstillet. Men dét er ikke tilfældet. Følgende lette 2- og flerstavelsesord hos Sthen har det forventede 1.-ledstryk:

'hoffmodt, 'forsyn, 'anslag, 'embidt, 'kallffskyng '-skind', 'hußbondt, 'arbeydtt sb., 'allmyß 'almisse', 'korprest, 'hoffmand, 'hygtiidtt 'højtid', 'mord Brand, 'kiøbmendtt etc. - I alt over 100 med 2 stavelser.

'Børighskaff ( $\varnothing=0)$ 'borgerskab', 'dannemendtt 2 g., 'greffue dømme, 'Iunckerskab, 'Røgeløße 'ryggesløse', 'gerighett, 'Cannickedom, 'helliigdage, 'prcedickstaalld 'prædikestol', 'fattigdom, 'Sogne degen 'sognedegn', 'Euenturs 'eventyrs', 'egteskaff 4 g., 'danne mands, 'danemandtt, 'Sogneprest 2 g., 'Embitz Broder (udtalt -bror), 'euighe, 'hymmerig 23 g., 'allerdom, 'Illdebrandtt, 'wederlag(i)s, 'kierlliighett 2 g., 'hiellpeLøße (ubøjet i udtalen), 'fader løße (do.), 'Rigeliig, 'hoffmod hett. - I alt 55 belæg med over 2 stavelser, der alle har 1.-ledstryk pga. reglen om 'sommerfugl, 'hjertekammer samt bøjningsudvidelse af 2-stavelsesord ('evige).

\section{Modeksempler med 2.-ledstryk}

Der er 6 modeksempler, hvor vi venter 1.-ledstryk (lette ord), men finder 2.-ledstryk:

skind'seck, skrog'Iß (men 2 regelrette ekss. på 'skrogis), Rig'dom 3 g. (33 g. 'rigdom), ar'mod 5 g. (24 g. 'armod), ploff'dreng, molld 'seck 'muldsæk'.

De optræder alle kun i rimstilling, fx 
Oc 'syger 'att hun 'er saa 'viiß

'Men hun 'Bygger 'alltt paa skrog'Iß

Det er vanskeligheden med på én gang at tilpasse rytme og rim, der får Sthen til at forløbe sig mod sit sprog; ordene kán ikke stå i rimstilling, hvis de skal have deres regelrette 1.-ledstryk. -3 af de 6 ord forekommer også inde i en linje og har dér konsekvent regelret 1.-ledstryk. Og i øvrigt peger det samlede sproghistoriske materiale - og over 100 former hos Sthen - på, at sådanne tostavelsesord havde 1.-ledstryk.

\section{Modgang}

Ordet modgang står 1 g. som mod'gang, 2 g. som 'modgang. I min analyse (Brink 2018b) konstaterer jeg, at substantiverede verber i middelalderen følger verbets tryk, altså fx ud'kast, ned'løb. Dette harmonerer med Sthens mod'gang og ovennævnte ad'traa sb. Men hvis verbum og verbalsubstantiv afviger kraftigt fra hinanden, er det vel naturligt, at substantivet inddrages under den almindelige regel for 2-stavede sammensætninger, altså 'modgang. Begge udtaler kan altså tilhøre Sthens hverdagssprog.

\section{$U-$}

$U$ - påvirkes ej af tryk-omkastet; det har opr. tryksvagt $u$-:

w'christeligh, w'lycke 3 g., w'gunst, w'dødtt sb.'voldsom død', w'mage vb. 2 g., w'mage sb. 2 g., v'bliidtt fk. 4 g., w'millde 2 g., v'rett, w'dulltt 'udulgt', w'skiell 'uretfærdighed', w'ferdtt 'ufærd', w'magh sb., w'glad, w'milld, $V$ 'stadig.

'wkysk'hedtt, 'wretth 2 g. (modeks.), 'wßyun 'slemt syn, utøj' 2 g., 'wkree 'kryb', 'vlertt 'ulærd', 'wraad 'uråd', 'wglad.

Som det ses, langt flere 2.-ledstryk end i dag, men ikke efter tungordsreglen.

\section{Andre upåagtede interessante former (alfabetisk ordnet)}

Mens det kun har ringe betydning for de ovennævnte metriske og trykmæssige forhold, om håndskriftet (det tilgrundliggende og ældste, AM $808,4^{\circ}$ ) er egenhændigt - der skal meget til at forvanske hele stavelser, og 
hs. er præget af sikkerhed og orden (Stedstrups forord) - så er det ikke uvæsentligt for de nedenstående detailfonetiske iagttagelser. AM 808 er skrevet af to forskellige hænder, den 1. dog kun i de første 287 linjer, der absolut ikke ser ud til at afvige sprogligt fra resten. Hs. er »fra begyndelsen af 1600-tallet«, og kúnne derfor godt være skrevet af Sthen selv - han dør i 1610 - men er altså i hvert fald ikke fra opførelsestiden og er dermed en afskrift. Men desværre går udgiveren slet ikke ind på dette spørgsmål. Hvis det ikke er Sthen selv, tillader jeg mig at tro på en i det væsentlige pålidelig afskrift.

andskens 'alskens' 3.604. Jeg har ledt forgæves i dialekter og ældre nordisk efter denne. Individualisme? Måske, men lige interessant for dét: fjernassimilation udløst af svagere lyd; der er 5 kontoider i træk at holde styr på (inkl. syllabisk $n$ ).

Anthen 'enten' flere g. $-A$-form er stærkt udbredt i jysk, men ej i andre dialekter. Der er tale om den oprindelige form < annat twaggja/twiggja, der - ellers - fak. får en lidt mystisk $i$ - eller palatal-omlyd $>$ enten.

arm sb. 1.460 og arm adj. 3.838, 3.1508 kan kun læses 2-stavet, dvs. med svarabhakti. Gammel lav-kbhsk. svarabhakti er belagt skriftligt nogle gange før 1840, men fortaber sig. ØMO har den ikke klart, idet alle belæg her har »vokalisk« $r$, og da bliver stavelsesantallet svært at fange. Den ældste videnskabelige sjællandske dialekt-kilde, Kryger f. 1844, noterer det uanfægtet i 1 stavelse med langt stødt »mørkt« $a+r m$. Så svarabhakti har næppe været obligatorisk. - Karakteristisk staver Sthen det $<$ arm $>$ til ære for traditionel skrift, og så må skuespilleren selv om resten.

Beedre 3.791 kan i Sthens bogstavering kun afspejle lang V. (Han skriver det $21 \mathrm{~g}$. < bedre>, men dét strider ikke imod lang V, ja, nedsætter end ikke sandsynligheden herfor, da han kun sjældent vokalfordobler i denne ordtype). Formen var obligatorisk i kbhsk. i begyndelsen af 1800-tallet, men falder for den generelle V-forkortelse foran $ð$ (nе’ $>$ neð' osv.); den holder sig endda lidt kunstigt i teaterkredse langt op i 1900-tallet. Da Vforkortelsen foran $\partial$ er tidligst i sjællandsk dialekt (Da.Rm. §33), bliver det interessant at se, om langvokal skulle findes her hos de ældste meddelere. Det gør den! ØMO har optegnet ['bce.ðro] 2 steder, i Nord- og Nordvestsjælland.

Creatur 3.1729 udtales 'kretur (eller 'kretter, almindelig i dial.), en velkendt form, der mest bringes som eks. på Sthens respekt for traditionel stavning på bekostning af skanderingshjælp.

Der og især her har ofte afledningerne dere, here, der vel at mærke passer metrisk (ofte i rimstilling). Dialektalt kendes de gamle tostavelses- 
former kun fra jysk, men de har altså også eksisteret i sjællandsk. Der er tale om et analogisk statisk -e som i ovre, af'e.

dreffue $1.299=$ drabe med $v / w$-lyd. Dialektalt kendes $v$-form ikke fra sjællandsk og kbhsk., kun fra mønsk, lolland-falstersk, fynsk m.m. (hvor det endda hedder 'drcefde i præt.; ØMO). Ordet var stort set litterært, idet man normalt sagde slå ihjel. Men formen eksisterede altså også i Roskilde.

due 'være tilstrækkelig' 1.456 kan kun læses ['du'ə]. I dag: [du' $d u$ 'ว / du. ]. 2-stavet udtale i inf./præs. findes i et stort jysk område, og i bornholmsk, men ellers kun på Ærø og Strynø, JO, ØMO. Vi venter overalt *due < duga og stødløs præs. *du·er $<$ dugir. Den nuværende énstavede er vel proportionsdannet efter præt. $d u \cdot \partial \partial$, hvor man ikke kan høre, om inf./præs. har -ə. Særlig reduktion i præs.: dur uden stød, ligesom nu i brur, kan have befæstet enstavelses-formen. En læseudtale i dette almindelige ord ville ikke ligne Sthen (og skriften vaklede).

-en: stærk verbal præt. part.: sidenn werdenn er Bleffuenn saa vndtt ('ond', rimer på stundtt 'stund', dvs. uden udtalt $t$ ); att ieg er kommen thiill arbyedtt oc wegtt ('vagt' sb.) 3.239. Han har overvejende vaere + -en i bleven og kommen (14 -en-belæg), men have + blevet ( 2 belæg), og $1 \mathrm{~g}$. jeg er blevet. I sidste eks. altså ingen kongruens.

Herudover findes -en i jeg var slagen og dragen og han blev bårenhun var ud'huggen og skåren - hans kloer var skårne samt reven sg. og revne pl. (begge appositionelle) og de er trevne (trives), men altid have + -et (båret, slaget, varet, taget, $\mathrm{i}$ alt mange g.).

Hjælpeverbet vaere tager altså næsten altid kongruerende -en, mens have synes fast at tage -et.

Sthen står, som det ses, det gamle, oldnordiske stadium nær, men at han ikke blot fortsætter en skrifttradition, fremgår af, at dette stadium for længst var blevet stærkt forstyrret (Skautrup I 274, II 51, 57, 200).

Ifølge alle håndbøger har sjællandsk dialekt her ubøjeligt -əð; jysk og kbhsk. derimod ubøjeligt -ən (Da.Rm. §117). Men sådan var det altså ikke på Sthens tid.

fenedij 1.476 'Venedig'. Udtalen med $f$ - er velkendt (Da.Rm. §93), men her står det med stærktryk på '-di' ( Turkij, mandlig udgang), hvad der må tages for gode varer hos den rimsikre Sthen.

giort part. udtalt $\boldsymbol{g}(\boldsymbol{j}) \boldsymbol{o}^{\prime} \boldsymbol{r} \boldsymbol{t}$ fremgår af rimet på førtt $1.787 \mathrm{og}$ skrives i to tilsvarende rim udtrykkeligt gjørtt, 2.806, 3.1453. Ø-form i præt.part. findes sporadisk i sjællandsk og andre dialekter. Det er, naturligvis, analogisk (morfembevarende) efter inf./præs. 
-gn: Songne presten 1.434. Udgiveren betragter det som en lapsus for Sogne. Men dét er helt usandsynligt. Udtalen $\eta(n)<\gamma n$ er som bekendt almindelig i svensk og norsk, i skånsk kun mod vest, og i bornh. slet ikke. Udenfor skånske kilder findes den ifølge GG §290.3 kun »sporadisk« omkring år 1500. Med et væld af modeksempler.

I kbhsk. har vi: Dronning Elisabet f. 1501 wongne 'vogne'; Fr. III (f. 1609)'s håndfæstning 1648 p. 123: Paa Olborig byesz vengne (mange modekss.); Hans Mogensen f. 1525 i oversættelsen af de Commines: wonge pl., voungborg, vongborrig (flere modekss.); Abrahamson (f. 1744) 1812: $g n$ udtales i dagligsproget ofte, som om der stod et $n$ foran [!], fx lingne; fru Dannemand f. 1790 (opvokset i jævne kår i Nyboder) skriver vong i et brev til kongen (1816; p. 87). Endelig havde min gode ven Jan Katlev, og hans bror, formen i ordet vogn (inkl. sporvogn). Men der er et væld af høje og lave kilder uden. Den sejrende udtale kan umuligt være skriftbestemt, eftersom vogn i alle de øvrige gamle kilder uregelmæssigt udtaltes med $[w]$ i stedet for det af skriften anviste $[\gamma]$ (Da.Rm. §37).

De kendte ældre udtaler i fremmedord: Angnes, Angnete, mangnet, singnet må være fonotaktisk bestemt heraf (og fremmet i tryksvag stilling), idet de er indkommet senere end lydloven $\gamma n>\eta$. Jf. også lat. magnus, ignis osv., om hvilke min latinlærer hævdede, at de ifølge Quintilian udtaltes mannus, innis osv.

Jeg har ikke kunnet finde herhenhørende sjællandske belæg i det udkomne af ØMO. Men udtalerne attesteres af det gode vidne Ole Kollerød f. 1802: songnefogde, songnens (fk.), vaangen, udsang, toengnebog (modeksempler). Sthen står ikke alene.

tockis 'tykkes' 1.361 (1-stavet tøks passer bedst, som andre deponentia samt svensk) har ø-lyd som hos visse akademikere f. før 1840 (jf. ODS). Udtalen må være lydret, men dét er den nuværende med [y] utvivlsomt også, jf. adj. tyk.

hage 'have' vb. 1.450. Denne og lignende hyperkorrekte former viser, at efterlyds $[k>\gamma>w]+$ bagtunge-V i sjællandsk er fuldbyrdet allerede før Sthen. Jf. klassisk sjællandsk $[k \alpha \cdot w, h \alpha \cdot w]$ kage, hage osv. Sthen har ikke kunnet høre forskel på ord, der normalt blev skrevet med $<$-v $>$ (have, stave) og dem med $<-\mathrm{g}>$.

heen adv., fx 3.858, skrives $11 \mathrm{~g}$. således. Det må betyde [hee'n ]. [he'n] kendes ej i dansk. At han $8 \mathrm{~g}$. skriver hen peger kun svagt på, at han også skulle have kort V. Formen [hce'n] er velkendt i fynsk, men fraværende i sjællandsk, ØMO. Ifølge Da.Rm. p. 544 er ordet ikke lånt $<$ mnty., men kommer $<$ nordisk heðan 'herfra', der får normalt $\partial$-tab $>[$ hae' $n]$ (jf. fx 
mens, Hven) og fonotaktisk tilpasning til accent 1 (det er jo énstavet), der afløses af stød på V. Den almindelige forkortelse til [høen(')] kan jeg ikke forklare.

hiorde 'hyrde' 1.449, hiurde 1.454. Denne $r$-brydning er ellers kun kendt i jysk med paralleller i fynsk (ØМО). Opr. hirðir > hyrðce (runding foran rundet $r$ ) > hjurðce (r-brydning) > jorðce ( $h$-tab og V-åbning) > jo·rce (V-forlængelse og $\partial>$ nul); dette i konflikt med V-forlængelse allerede på stadiet hyrðc: $>$ hy $\cdot r ð c e$ (lang V skal ej brydes) $>$ hy $r e=$ den klassisk sjællandske form; litterært 'hyrdo. - hiørde 1.468 og 3.322 kan være en blandingsform eller evt. en sidste lydret fremskydning: jo > jø.

(i) huge 1.648 'i hu'. Med udgiveren mener jeg, at der skal læses $i$ håwe, idet det rimer på sove, der ved lapsus er skrevet søffue. Og i 1.651 skrives da også wthy mynn hoffue. Håw o.l. er almindelig i jysk (inkl. »folkeviseordet« elskov), men kendes ikke i klassisk sjællandsk (ØMO). Ikke desto mindre findes den i Rimkrøniken fra 1400-tallet og i andre gamle sjællandske kilder. Sågar Oehlenschläger f. 1779 Kbh. skriver Hvor staar Hoven i... 'Hvordan går det i...' (ODS). Også fornsvensk har begge former, så der er intet mærkeligt $\mathrm{i}$ at finde $a ̊ \mathrm{i} 1570 \mathrm{i}$ Roskilde.

-ig: willig 'vilje' står 5 g. med -ig-form (wiilliig o.1.): 1.114, 2.554, 2.802, 2.557, 3.1630, med talrige modeksempler på -e. Den tilsyneladende udtale på [-i] er velkendt i jysk, men ikke belagt i sjællandske kilder. Den kunne dårligt forekomme i sjællandsk, da den forudsætter apokope: wiljce $>* *$ wilj med fonotaktisk tilpasning $>$ wili, hvor sjællandsk tværtimod netop bevarer [-jə], Ejskjær 1970: 67. Klassisk sjællandsk er i talrige belæg helt entydigt: ['velo] med det forlængst i mda. udviklede $i>e$. Det må Sthen også have sagt. Willig er da formentlig en omvendt skrivemåde. Han síger velo, men véd, at det ikke staves ligefremt (trad. normalt $<$ wilghe $>$ ), men slår så ind på sporet wenligh, som han i lighed med almindelig sjællandsk dial. udtaler ['vœenlə(ठ)] som generelt ved skriftens <-lig>. Tilsvarende $\beta ø r i i g$ (sørge) 3.245 og verig 3.1125 (vaerge sb., udtalt vare el. varre, jf. <were> 3.1602) og ßellig 3.1241 (scelge, udtalt scelle). Vi har da her et vidnesbyrd om, at sjællændere født i 1542 allerede havde denne svækkede/analogiske endelse, $[-ə(\partial)]$, i venlig og andre på -ig.

Klusilsvakkelsens 4. stadium, in casu $[\gamma>j]$ efter fortunge-V, sætter jeg (Brink 2018a) til 1375-1500 i almindelig stilling i kbhsk. Sthen har i hvert fald ét godt indicium herpå: mig 3.1208 rimer på queg adj. ('kvæg, levende'). Æmda. fik vel [mik>mig (2. stadium) $>$ meg $>$ me $\gamma$ (3. stadium) $>$ mej (4. stadium) $>$ maj . Som topfrekvent tryksvagt ord er det sikkert gået i spidsen for alle de pågældende lydlove, jf. sv.-no. mej. Altså sagde 
den gode rimer [maej] og dermed [kwaj] (oprindelig kortstavet: $<k w i k$ ), som bevaret i kvaj.

kor sb.pl. 'kår' 3.174 viser en kortvokalisk stødløs udtale, da det hos den rimsikre Sthen rimer på wor 'var' i dettes velkendte sjællandske korte a-form. Sthen ville uvægerligt have brugt dobbeltbogstav, hvis hans V i $k a ̊ r$ havde været lang. - Den store gruppe af oprindelig kortstavede enstavelses-ord (»alfa-ord«) er stadig i rm. overvejende korte og stødløse (tal, ven, bcer osv.), men har i stigende omfang fået V-forlængelse (sal, man sb., spor osv.), en udvikling anført af kbhsk. med jysk og sejrøsk i bagtroppen, Da.Rm. §58. Kår har vidt udbredt bevaret kortform i jysk (og hos Høysgaard), men der er kun langvokaliske belæg i ØMO.

Løen 1.677, ordet løn 'belønning'. Jeg ansætter C-forlængelsen af $n$ efter $\varnothing$ (og den efterfølgende V-fork.) i kbhsk. til at være sket 1450-1550 (Brink 2018a). Sthen f. 1542 kan altså udmærket tænkes at have gammel langvokalisk form, hvad hans stavning kraftigt tilsiger. Løen turde være entydigt langt. Herudover er det lidt uklart: <skøne> adj. 4 gange, mod $<$ skønne> 8 g. 3.529 Lønn $\sim$ Rønn 'erfaring' giver kun en svag strømpil mod kort V, mens 3.640 Løn Bøn peger kraftigere på lang V - i ordguirlandernes tid, hvor der trods alt spores tendens til lang $\mathrm{V}$ foran enkelt $\mathrm{C}$. I øvrigt kan han have vaklet.

mogett 'meget' 2.159 (mange modekss.) overrasker noget. Jysk og fynsk, vest- og midtlollandsk samt enkelte vestsjællandske sogne samt Høm i Midtsjælland har ø-form. (Jysk har varianten [möj'] o.l., som jeg, modsat Anette Jensen 2009, er overbevist om skyldes det oprindelige mjok). - Næsten hele Sjælland samt Møn og Falster har $a$-form. - Men Kbh., Tåstrup og visse såkaldte øresundsmål (St. Magleby, Skovshoved) har fakultativ $\varnothing$-form. I Kbh. uddøde møjeð dog omtrent med Frederik VI f. $1768 \mathrm{Kbh}$., siden man bemærkede udtalen hos ham (Da.Rm. p. 745); ligesom allerede den kbhsk.-nære 1727-kilde nævner, at ø-formen ikke er standard. - Skånsk-bornh. har helt igennem den urundede variant. Vi venter altså cej i Roskilde anno 1570, men som belæggene antyder, og som Anette Jensen formoder ud fra div. forhold, har öj sikkert haft endnu større udbredelse før de klassiske dialekter. I det lange løb taber ø-formen, ikke kun fordi det mindre æ-område omfatter hovedstaden (hvor $c$ var fak.), men også, fordi ø lider nederlag selv her. Hvilket vel igen hænger sammen med, at allerede oldsproget havde dobbeltformer: mikit/ mykit, hvor $y$ trods alt kun er udviklet af de få former i fællesnordisk, der havde $u$ i 2. stavelse: myklum, myklu ved kombineret u-omlyd. (Tak til Anette Jensen for hendes grundige afhandling). 
Reffuell 1.617 'Reval, Tallin' viser en lidet påagtet infortissvækkelse. Stednavnet er formentlig lånt længe efter den æmda. infortissvækkelse, men har altså alligevel fået fonotaktisk bestemt $ə$. En parallel er nuværende sådan "såtten«, der lånes i 1400-tallet, endda sikkert med fak. bitryk, der plejer at holde på - $a$. Sådanne nyere lån svækkes almindeligt $\mathrm{i}$ jysk, så at der fx er ə i Ulla, mulig, Ferguson, bryllup, sodavand (Da.Rm. p. 220, 456, JO). Men i sjællandsk og kbhsk. ses de sjældent. 1727-kilden har dog talrige af dem.

nagne 'nøgne' adj.pl. 2.622 overrasker. Jysk-fynsk-bornh. har $a$, der ikke er optegnet i sjællandsk (se fx Kortetc. p. 65, 160, Andersen 1958). $A$-formen modsvarer oldn. nakinn, mens nøgen er et kompromis mellem dette og oldn. nökwiðr med i-omlyd (lang stav.): $a>c e$, og w-omlyd: $a>$ $\ddot{o}$, her, som ofte, også i østnordisk.

Nul pro - $\boldsymbol{t}$ i præt.(part.): hørde infinitiv (Men 'guds ordtt 'wiillthu 'icke 'hørde 1.672) skrives flere gange $=$ Sthens præt. $<$ hørde $>$, hvoraf let ses, at præt. udtaltes uden $d / \partial$. Denne sidste lydrette udtale uden den senere tempus-tydeliggørende dental er velkendt i jysk og fynsk, men er ellers ukendt i sjæll.-kbhsk.

Tilsvarende rimer 1.818: att fram 'førde inf. giørre, og 3.291: førde hørde begge infinitiv, ligesom 3.280 giørde tiill 'hørde præt., der må tolkes som »gjøre præt. høre præt.«; 2.212 og 2.417 har lerde 'lære' infinitiv.

Også herde 'hærdede' 2.332 viser oprindelig bøjning uden præt.-dental. Og det samme gælder ßollde 'solgte' 2.621, 3.850: Det oprindelige $d$-saldi - bortassimileres, og vi får sålle, der hos Sthen endnu ikke har fået ny præt.-dental. Hvilket fremgår af rimet: hollde inf., der ikke kan have foredrags-[ld], idet Sthen helt igennem er mundtlig, jf. de mange kortformer imod skriften. I øvrigt var foredrags-[-ld-, -nd-] ikke obligatorisk.

Også wolld 'magt' Bolldtt 'solgt' 3.934, og wolldtt 'magt' ßolltt 3.1523 viser manglende fleksiv: [sål'], eftersom $u$ dlydende $<-1 \mathrm{~d}>\mathrm{i}$ foredragssproget ikke udlæstes efter bogstaven, Da.Rm. §65. Tilsvarende 2.66 Iord $\sim$ giortt (altså den oprindelige fk.-form).

Tilsvarende kiende præt. $\sim$ ende sb. 3.123, 3.775, og kiende præt. $\sim i$ hende sb. 3.185. Og wende præt. ende sb. 3.879 samt wenthe 'vendte' $3.1224 \sim$ ende $\mathrm{sb}$.

Passiv: nødis 2.628 må læses nøds med den oprindelige mediopassiv. Tilsvarende må Bygis 'bygges' 3.610 læses bygs. Jf. nuv. behøvs, gaelds, kløjs, skcends, slås, syns. 
Sing. pro plur. i præsens. I 1.765:

Oc 'Idelliig 'ere Baade 'wrede oc 'wrannghe

må ere læses i 1 stavelse, og det kan ikke skyldes nogen af de to nævnte apokoper, men derimod, at talesprogets sg. pro pl. allerede i høj grad er slået igennem. Linje 1.853 are pl. skal dog udtales ortodokst. - I 1.865 noteres udtrykkeligt sg. Boer vb., skønt subjektet er fencker 'unge tøjter'. Også wiille 'ville' præs.pl. 3.69 kan kun læses som vil.

skudder vb. 'skyder' 1.637. U-form kendes fra jysk, fx vendelbomål, men ej fra ømål, JO, ØMO. Analogi efter skudt og skud sb. Den var mere nærliggende på stadiet skjude inf.-skydder præs. Om V-forkortelsen se Da.Rm. p. 233f.

sprock 'sprog' 3.1006, 3.1621 viser lån fra mnty. for anden gang, nemlig efter 1375 (Brink 2018a), så at det unddrager sig klusilsvækkelsen, der ramte det samme ord første gang: sprog. $K$-varianten uddør først i 1600-tallet. Den findes fx konsekvent hos Gerner $1629 \mathrm{Kbh}$. Sthen har aldrig $<-\mathrm{k}>\mathrm{i}$ ord med klusilsvækkelse.

[sw-, $\boldsymbol{t w}$-, $\boldsymbol{k} \boldsymbol{w}$-]. Sthen bruger konsekvent bogstavet $<\mathrm{u}>\mathrm{i}$ dækket forlyd: suyn 'svin', Suerre 'sværge', ßuenne 'svende', suellthe 'sulte', hugsualle 'husvale', ßuige 'svige', Thuenne 'tvende, to', queg 'levende', quede vb. 'kvæde', men $<\mathrm{w} / \mathrm{v}>$ (langt oftest $<\mathrm{w}>$ ) i udækket forlyd: wiße sb. 'vise', werre 'være', wiill 'vil', vreed adj. o.m.a. Og hans $<\mathrm{u}>$ står ellers næsten altid for det med $[w]$ nærtbeslægtede $[u]$, bortset fra konventionen <-ffue $>$. $-W$ - $>v$ - kan ansættes til 14501550 (Brink 2018a); den seneste undertype gælder netop, ifølge alle håndbøger, dækket w-, som er bevaret i skånsk-bornh., og i jysk, herunder i det område, der ellers har $[v]+$ fortunge-V. Sthens konsekvens her usandsynliggør, at han blot ligger under for tidens forvirrede traditioner.

Dronning Elisabet f. 1501, der skriver uafhængigt af dansk tradition, staver ganske tilsvarende konsekvent welked 'hvilket' osv. versus suen 'svend' osv. og (på sin fransk) soyre 'svare'.

'thett 'det' 1.729 gengiver klassisk sjællandsk ['deð], idet det rimer på ordet smed $\mathrm{sb}$. hos denne kræsne rimer. At $e$-formen fandtes allerede i 1570 (i stedet for ældre $a<a$ ), kunne ikke skønnes på forhånd.

I 12 tilfælde har vi mødt former hos Sthen 1544 Roskilde, som man ville have forsvoret eksistensen af, fordi de ikke findes i klassisk sjællandsk (= de max. rm.-fjernt talende f. 1797-1880, Brink 2011), men derimod i andre dialekter, især jysk og bornholmsk: 
1) dere/here, 2) -en i part., 3) hjorde, hjurde, 4) du·ə vb., 5) skudder 'skyder', 6) mgl. præt.-t i hørte etc., 7) anten konj., 8) gjørt 'gjort', 9) nagne 'nøgne', 10) møjed 'meget', 11) kortvokalisk kår sb., 12) hoe'n 'hen'.

I 8 af disse $(2,4,6,7,9,10,11,12)$ er der tale om en oprindelig form, mere eller mindre stemmende med oldnordisk, fornsvensk osv. Så egentlig er det ikke sært at finde dem i sjællandsk i 1570, medmindre man som Brøndum-Nielsen (1951: 92-94) tror, at dialekterne stivnede i middelalderen. Disse former er så blot uddøde i sjællandsk før ca. 1800. - Det er mere overraskende, at 4 af trækkene er sekundære, dvs. opstået efter æmda. og overleveret i andre egne af landet, men uddøde i sjællandsk før ca. 1800. Altså kommet - og gået igen. Man skulle jo vente, at here, dere, der naturligvis oprindelig var en succes, ville fastholdes, fordi de udfyldte et behov og følgelig først blev slået ud af rm., da dettes pres blev stort efter 1900. Og tilsvarende skudder. Hvis denne analogi føltes uimodstålig før 1542 - og ellers var den jo ikke opstået - skulle man tro, at den vedblev at have magt over sindene. Men så enkelt er det altså ikke.

Jeg kan anbefale læsning af Kortvending. Ikke for dramatikkens skyld, men for sprog- og almenhistoriens skyld. Trods alverdens ordguirlander er han ret nem at læse, med udgiverens hjælp. Der er et væld af gamle ord og former, og det er en sand sport at skandere hver linje korrekt vel vidende, at forfatteren har uhyre få metriske fejl. Til gengæld gør hans ærbødighed mod tidens traditionelle skrift og de mange skriftkonventioner, apokoper, indsættelse af ikke for ej, hvilket for hvad o.l., det hele til en morsom syssel.

\section{Litteratur}

Abrahamson, W. H. F.: Versuch einer vollständigen dänischen Sprachlehre für Deutsche. 1812.

Andersen, Poul: Fonemsystemet i Østfynsk. 1958.

Arnholtz, Arthur: Det mundtlige Foredrag. 1961.

Brink, Lars: »Uklassisk vendelbomål i 3 generationer« i Jysk, ømål, rigsdansk m.v. Århus 2011.

Brink, Lars: Sound Changes in Late Middle Danish 1350 -1500 (www.larsbrink. dk, rev. 2018) (=2018a).

Brink, Lars: »Stød, tryk og tonegang« i Dansk sproghistorie 2, DSL 2018., (= 2018b).

Brink, Lars: »Den metriske adaptation« i Studier i Nordisk Selsk. f. Nord. Fil. 2019. 
Brink, Lars \& Jørn Lund: Dansk Rigsmål I-II. Kbh. 1975. (= Da.Rm.)

Brøndum-Nielsen, Johs.: »Brugen af nægtelserne ej og ikke« I: »Studier og Tydninger«. 1951.

Brøndum-Nielsen, Johs.: Studier og Tydninger. Kbh. 1951.

Brøndum-Nielsen, Johs.: Gammeldansk Grammatik I-VII. Kbh. 1928-1971. (= GG)

Dannemand, Frederikke: »Breve« i Kvinder i dansk Historie (Red. Bering Liisberg) 1916.

Ejskjær, Inger: Fonemsystemet $i$ østsjoellandsk. Kbh. 1970.

Elisabet, dronning: 16 breve. De 2 første i Lindegård Hjorth: »Til dronning Elisabets breve« i Festskrift til Kristian Hald 1974. Resten i Allen: Breve og Aktstykker til Oplysning af Chr. II's og Fr. I's Historie. 1854.

Fafner, Jørgen: »blankvers« i Den Store Danske Encyklopcedi 31995.

Fischer-Jørgensen, Eli: Tryk i celdre dansk. 2001.

Gerner, Henrik: Orthographia Danica. Kbh. 1679.

Gammeldansk Ordbog: nettet. (= GDO)

Geheimearchivet: Samling af danske Kongers Haandfaestninger. Reproudg. Kbh. 1974.

Hansen, Aage: Den lydlige udvikling i dansk. I Vokalismen 1962.

Jensen, Anette: »Noget om meget i danske dialekter.« I Dialektforskning i 100 år 2009.

Jysk Ordbog: nettet. (= JO)

Kalkar, Otto: Ordbog til det celdre danske sprog 1-4 1918 (nyudg. 1976)

Kollerød, Ole Pedersen: Min historie. 1840. Udg. i Kbh. 1978.

Kortetc.: Kort over de danske folkemål 1898f. . Af M. Kristensen \& V. Bennike.

Kristensen, Marius: Bidrag til den jyske litteraturs historie. i Dana, 1894.

Kryger, J.K.: »Bidrag til nordsjællandsk Lyd- og Bøjningslære.« Blandinger 5. Hefte. Udg. af UJDS 1887.

Mogensen, Hans: Hans Mogensens overscettelse af Philippe de Commines memoirer. DSL 1913.

Ranch, Hieronymus Justesen: Karrig Nidding. En skolekomedie fra ca. 1600. Ved Leif Stedstrup. DSL 2012.

Skautrup, Peter: Det danske Sprogs Historie I-IV. 1944-1968.

Sthen, Hans Christensen: Kortt wendingh. En skolekomedie fra ca. 1570. Ved Leif Stedstrup. DSL 2013.

ØMO: Ømålsordbogen. Udg. af IDD ved Kbh.s Univ. 1992-

1727-kilden: Dansk Rigssprog. Udg. af Caroline Henriksen. Kbh. 1976. 